\title{
Risk of herbicide mixtures as a key parameter to explain phytoplankton fluctuation in a great lake: the case of Lake Geneva, Switzerland
}

\author{
Vincent Gregorio - Lucie Büchi • Orlane Anneville • \\ Frédéric Rimet $\cdot$ Agnès Bouchez $\cdot$ Nathalie Chèvre
}

Accepted: 25 July 2012/Published online: 9 August 2012

(C) Springer Science+Business Media, LLC 2012

\begin{abstract}
Mixture risk assessment predictions have rarely been confronted with biological changes observed in the environment. In this study, long-term monitoring of a European great lake, Lake Geneva, provides the opportunity to assess to what extent the predicted toxicity of herbicide mixtures explains the changes in the composition of the phytoplankton community next to other classical limnology parameters such as nutrients. To reach this goal, the gradient of the mixture toxicity of 14 herbicides regularly detected in the lake was calculated using concentration addition and response addition models. A temporal gradient of toxicity was observed which decreased from 2004 to 2009. Redundancy analysis and partial redundancy analysis showed that this gradient explains a significant portion of the variation in phytoplankton community composition with and without having removed the effect of all other covariables. Moreover, species that are significantly influenced, positively or negatively, by the decrease of toxicity in the lake over time are highlighted. It can be concluded that the herbicide mixture toxicity is one of the key parameters to explain phytoplankton changes in Lake Geneva.
\end{abstract}

Keywords Microalgae - Mixture toxicity - Pesticides . Risk assessment $\cdot$ Redundancy analysis

V. Gregorio $(\varangle) \cdot$ L. Büchi · N. Chèvre

IMG, Faculty of Geosciences and Environment, University

of Lausanne, 1015 Lausanne, Switzerland

e-mail: vincent.gregorio@unil.ch

O. Anneville $\cdot$ F. Rimet $\cdot$ A. Bouchez

INRA, UMR CARRTEL, 75 Av. de Corzent, BP 511,

74203 Thonon Les Bains Cedex, France

\section{Introduction}

Worldwide pollution caused by chemicals and the adverse effects they may produce is now widely recognised (Schwarzenbach et al. 2006). Risk assessment is regularly used to highlight the substances of concern in a given compartment of the environment (Barnthouse 2008). The risk can be evaluated before the substance comes to the market (European Commission 2003) or site-specific or region-specific assessment can be carried out (for example Ward et al. 2007; Williams et al. 2009). However, until now substances have usually been evaluated individually, which doesn't reflect reality. In fact, organisms in the environment are typically exposed to a wide number of chemicals combined together. Some authors therefore propose assessing the risk of mixture (for a review see Chèvre and Gregorio 2012). Such an approach is also discussed at the policy level (Kortenkamp 2011).

However, risk assessment, even if it takes mixture effects into account, remains an assessment based on laboratory testing and often simple assumptions. For the widely used predicted no-effect concentration (PNEC; European Commission 2003) value, a defined extrapolation factor is applied to the lowest ecotoxicity data, and is assumed to bridge the gap between the effects observed for single species in the laboratory and the effects expected in the environment. Even the species assemblage used in the Species Sensitivity Distribution curves (SSD, Posthuma et al. 2002) cannot reflect the diversity of the species and their interactions in the environment, and the hazardous concentration (HC) predicts the impact in terms of a fraction of affected species on a natural community, which is difficult to link with a concrete ecological reality. Furthermore, the mixture models are mathematical models that were validated primarily with laboratory studies on 
single species (Altenburger et al. 2000; Faust et al. 2003; Junghans et al. 2003).

There is therefore a need to confront the predictions of mixture risk assessments with observations in the field or, to state it differently, to establish whether mixture toxicity is a parameter that can explain changes in a given ecosystem. To the best of our knowledge, this has rarely been done. However the merging of ecotoxicology and ecology is essential to better understand the effect of toxicants on biodiversity (Beketov and Liess 2011). de Zwart and Posthuma (2005) tried to compare both the observed and modelled effects of pesticides in Dutch field ditches without being able to come to strong conclusions. But in another study, Posthuma and de Zwart (2006) successfully compared the effects of toxicant mixtures in Ohio rivers with changes in fish assemblage, which is more encouraging for further investigations.

In this study, we aim therefore to evaluate to what extent the predicted herbicide mixture toxicity can explain the changes in phytoplankton composition in a large lake in Europe in contrast to more classical parameters such as temperature or phosphorous changes. Since microalgae form the basis of the food chain as primary producers in the aquatic environment, it is essential to both study their evolution in lakes and to evaluate to what extent chemicals may affect them. Moreover, they are linked to important ecosystem services for humans like drinking water, fishing or tourism. Among other compounds, herbicides have a toxic mechanism of action (TMoA) that make them likely to act on algae (Chèvre et al. 2006) and are compounds measured primarily in surface water (Loos et al. 2009). In a recent review paper, Pesce et al. (2011) highlighted that very few studies linked herbicides concentrations with field observations at the phytoplankton community level. To reach our goal, we will therefore estimate the potentially affected fraction of algae species by herbicide mixture. This indicator will be compared to other parameters (temperature, phosphorous, etc.) in its potency to explain phytoplankton changes over a period of years.

The object of the study is Lake Geneva, which has $580 \mathrm{~km}^{2}$ and a maximum depth of $309 \mathrm{~m}$. It has been monitored for classical limnology parameters (temperature, phosphorous, etc.) since 1960, and for more than a hundred chemicals since 2004 by the International Commission for the Protection of Lake Geneva (CIPEL). Long-term values of environmental parameters and phytoplankton are therefore available. We used classical statistical ecological methods such as partial redundancy analysis (Legendre and Legendre 1998) to overcome the problems of confounding environmental factors when studying the correlation of changes in the phytoplankton community with herbicide mixture toxicity.

\section{Materials and methods}

Databases and data treatment

Four databases were used in this study (Fig. 1): (i) the measured herbicide concentrations, (ii) the physico-chemical features, (iii) the abundance of the phytoplankton species in Lake Geneva, and (iv) an eco-toxicity database of herbicides on algae in order to evaluate the risk of the pesticide mixtures. The three first databases were obtained from The International Commission for the Protection of Lake Geneva, which is responsible for the survey of Lake Geneva (Corvi et al. 2005; Druart et al. 2005, 2006; Druart 2007; Lazzarotto et al. 2005, 2006; Lazzarotto and Rapin 2007, 2008, 2009, 2010; Edder et al. 2006, 2007, 2008; Rimet et al. 2008; Rimet and Druart 2009; Rimet 2010; Ortelli et al. 2009, 2010). All the data of the first three databases were measured at SHL2, a reference sampling point in the middle of the lake and above its deepest point (Chèvre et al. 2008). This study focused on the spring period from March to May for the years 2004-2009, for which all the parameters' values were available. All data were collected in the epilimnion, which corresponds to the place in the water column where the primary production was the most important during spring.

(i) Herbicides concentrations: 80 herbicides were screened by HPLC/MS-MS from 2004 to 2009. During the period studied, 55 herbicides were detected but 14 were frequently found and quantified (atrazine, simazine, prometryn, terbumeton, terbuthylazine, terbutryn, chlortoluron, diuron, isoproturon, linuron, metobromuron, monolinuron, monuron, metolachlor). These 14 herbicides have been selected for the analysis and the others were neglected. (ii) Physico-chemical features: Six parameters were used for the analysis: Total phosphorus (TP), total nitrogen (TN), dissolved inorganic phosphorus (DIP), dissolved inorganic nitrogen (DIN), dissolved oxygen and temperature. The nutrient variables were already linked with phytoplankton changes in Lake Geneva (Anneville et al. 2002; Rimet et al. 2009; Tadonléké et al. 2009) but the influence of the chemicals' toxicity was not considered. Moreover, the ratios TN:TP and DIN:DIP were considered in the statistical analyses because they have already been shown to explain a part of the variation in the primary production (Tadonléké et al. 2009). (iii) Phytoplankton community: Phytoplankton was sampled on the twenty-first meter of water column with a Pelletier integrating bell, and species were counted with an inverted microscope in accordance with the Utermöhl technique (Druart and Rimet 2008; EN 15204 2006). The abundance was defined by the concentration of an algal cellular object of the species in a defined volume, the object being specific to each species. It could be per volume, the number of cells for unicellular 


\section{(i) Herbicides SHL2}

D - Herbicide concentrations for spring period A from 2004 to 2009

T -80 herbicides screened by HPLC/MS-MS

A iv) Ecotoxicity database

- EC50s and NOECs of algae species for the 14 selected herbicides (ii) Physico-chemical SHL2

- total phosphorus, total nitrogen, dissolved inorganic nitrogen, dissolved inorganic phosphorus, dissolved oxygen, temperature, DIN:DIP, TN:TP, sampling time - spring values from March to May for the years 2004 to 2009 .

\section{(iii) Phytoplankton SHL2}

- spring community compositions from March to May for years 2004 to 2009 .

- sampled from $20[\mathrm{~m}]$ depth to the surface with integrating bell. Primary production mainly located between 2 and $10[\mathrm{~m}]$ depth in spring - a total of 103 species monitored for the whole period

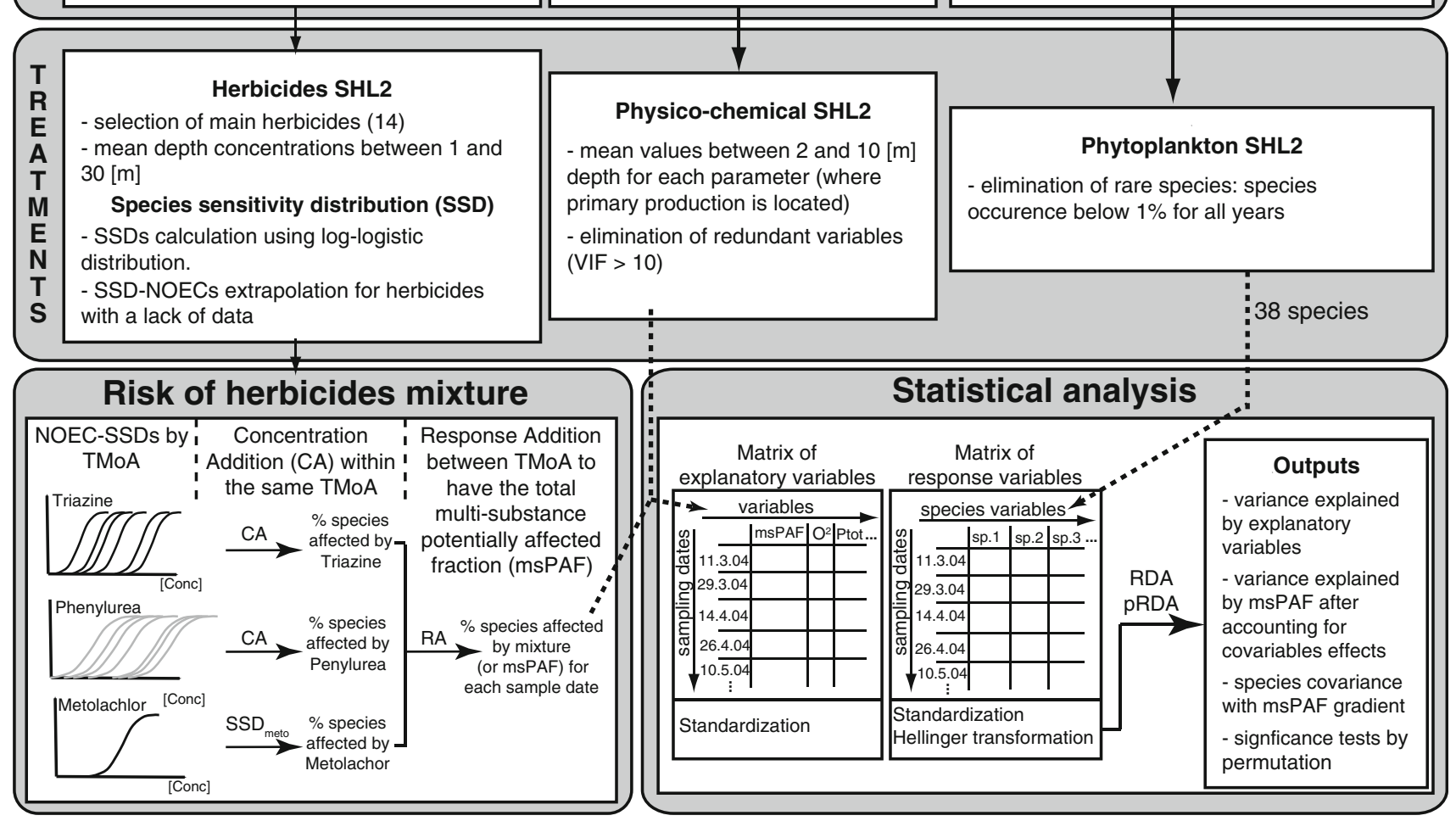

Fig. 1 General overview of the methodology applied to study fluctuations of algae species in community composition linked with herbicide mixture toxicity. The numbers (i-iv) correspond to the different raw database that were used. The figure summarizes the data

taxa, or the number of segments for filamentous algae or colonies for colonial species. (iv) Eco-toxicity database: herbicides toxicity data on algae growth (i.e. EC50 and NOEC data) were obtained from previous studies (Chèvre et al. 2006, 2007), completed with literature data from different databases [ECOTOX (2012); EFSA (2012); INERIS (2012); FOOTPRINT (2010); eChemPortal (2011); OPP (2012); AGRITOX (2012)].

\section{Risk of individual compounds}

The hazardous concentration potentially affecting $5 \%$ of the species (HC5) was estimated from the no-observed effect concentration species sensitivity distribution curve of the compound (NOEC-SSD; Posthuma et al. 2002). SSD curves were fitted with a log-logistic model (Eq. 1) and the risk quotient (RQ) of each individual herbicide was selection and treatments to create both explanatory (physico-chemical parameters) and response matrices (phytoplankton composition), which were explored by means of multivariate statistical analysis with redundancy and partial redundancy analysis

calculated by comparing the concentration measured in the lake to the HC5 of the substance (Eq. 2).

$\mathrm{PAF}=\frac{1}{1+10^{\left(\log \mathrm{HC}_{50}-\log \mathrm{HC}_{\mathrm{PAF}}\right) * \operatorname{lope}}}$,

where PAF is the potentially affected fraction of species by a substance concentration $\left(\mathrm{HC}_{\mathrm{PAF}}\right)$. $\mathrm{HC} 50$ and slope are the two scaled parameters of the SSD curves for the substance.

$\mathrm{RQ}=\frac{\mathrm{MEC}}{\mathrm{HC}_{5}}$,

where the MEC is the measured environmental concentration of a substance. The risk quotient (RQ) must be less than one to ensure that a given chemical presents an acceptable risk to the environment.

To overcome the problem of lack of data, which prevented the estimation of a robust NOEC-SSD for certain compounds, we extrapolated the curves from the 
EC50-SSD (SSD curves with Effect concentration $50 \%$ ) following the methodology proposed by Chèvre et al. (2006). To summarize, all EC50 s data were first fitted with a log-logistic distribution (Eq. 1) taking into consideration a common slope for substances within a group sharing a similar TMoA. A relative potency was calculated between the substances of the group. Then the NOEC-SSD was calculated for a reference substance in each group. This substance had the greatest number of available NOEC values. For all other substances the NOEC-SSD curves were extrapolated from the reference substance curve using the relative potencies. The results of the scaled parameters for the SSDs of each herbicide are listed in Table 1.

Mixture toxicity assessment

The multi-substance potentially affected fraction of species (msPAF), being the fraction of algae species that may be affected by the mixture of the 14 most frequently detected herbicides, was calculated for each sampling date (MarchMay, 2004-2009). We combined the concentration additivity (CA) and the response additivity (RA) models applied on the NOEC-SSD (Posthuma et al. 2002; de Zwart and Posthuma 2005; Chèvre et al. 2006). To do so, the 14 herbicides were classed in three different toxic mechanisms of action (TMoA), i.e.: two subgroups of photosynthesis inhibitors at photosystem II (triazines and phenylureas), and one group of cell division inhibitors (chloroacetamides). CA was applied on NOEC-SSD within the same TMoA (Eqs. 3 and 4) and followed by RA between the different TMoA (Eq. 5; Fig. 1).
$\mathrm{equ}_{i}=C_{i} \times \frac{\mathrm{HC}_{50 \mathrm{ref}}}{\mathrm{HC}_{50 i}}$

where $\mathrm{equ}_{i}$ is the equivalent concentration of a substance $i$ expressed as a concentration of a reference substance. All triazines are expressed as atrazine equivalent concentrations and all phenylureas as diuron equivalent concentrations. $C_{i}$ is the concentration of the substance $i$ with the same TMoA as the reference substance. $\mathrm{HC}_{50 \mathrm{ref}}$ is the hazardous concentration of the reference substance (atrazine or diuron) that would affect $50 \%$ of the species (NOEC$\mathrm{SSD}) . \mathrm{HC}_{50 \mathrm{i}}$ is the hazardous concentration of the substance $i$ that would affect $50 \%$ of the species (NOEC-SSD).

$\operatorname{msPAF}_{\mathrm{CA}, \mathrm{TMoA}}=\frac{1}{1+10^{\left(\log \mathrm{HC}_{\mathrm{Tef}}-\log \sum_{i}^{n} \text { equ }_{i}\right) \text { slope }_{\mathrm{TMoA}}}}$,

where $\operatorname{msPAF}_{\mathrm{CA}, \mathrm{TM}}$ is the multi-substance potentially affected fraction of species by the mixture of $n$ substances of a specific TMoA. Slope ${ }_{\mathrm{TMoA}}$ is the best-fitted slope parameter (in the log-logistic equation) for all NOEC-SSDs within the same TMoA. Note that the addition of the $\mathrm{equ}_{\mathrm{i}}$ is possible because we assume similar slopes of NOEC-SSD within a similar TMoA. The compounds only differ in their toxic potency.

The msPAF of algae by the whole mixture of herbicides, i.e. between groups of different toxic mechanisms of action, was calculated following RA (Eq. 5).

$\operatorname{msPAF}=1-\prod_{1}^{j}\left[1-\operatorname{msPAF}_{\mathrm{CA}, \mathrm{TMoA}_{j}}\right]$

within this case $j=3$ considering the three TMoA (triazines, phenylureas, cell division inhibitors).
Table 1 Best scaled HC50 (in $\mu \mathrm{g} \mathrm{L}^{-1}$ ) and slope of the loglogistic distribution (Eq. 1) for each individual SSD curve used in this study

\begin{tabular}{|c|c|c|c|c|}
\hline \multirow[t]{2}{*}{ Substances } & \multicolumn{2}{|c|}{ Scaled parameters for EC50-SSD } & \multicolumn{2}{|c|}{ Scaled parameters for NOEC-SSD } \\
\hline & $\mathrm{HC}_{50}$ & Slope & $\mathrm{HC}_{50}$ & Slope \\
\hline Atrazine & 126.47 & 1.30 & 17.95 & 1.30 \\
\hline Prometryn & 11.22 & 1.30 & 1.59 & 1.30 \\
\hline Simazine & 224.39 & 1.30 & 31.84 & 1.30 \\
\hline Terbumeton & 20.94 & 1.30 & 2.97 & 1.30 \\
\hline Terbuthylazine & 25.12 & 1.30 & 3.56 & 1.30 \\
\hline Terbutryn & 1.83 & 1.30 & 0.26 & 1.30 \\
\hline Diuron & 5.53 & 1.50 & 0.95 & 1.01 \\
\hline Chlorotoluron & 39.36 & 1.50 & 6.73 & 1.01 \\
\hline Isoproturon & 25.35 & 1.50 & 4.35 & 1.01 \\
\hline Linuron & 27.10 & 1.50 & 4.64 & 1.01 \\
\hline Metobromuron & 430.53 & 1.50 & 73.64 & 1.01 \\
\hline Monolinuron & 6.56 & 1.50 & 1.12 & 1.01 \\
\hline Monuron & 543.25 & 1.50 & 92.93 & 1.01 \\
\hline Metolachlor & - & - & 5.78 & 0.92 \\
\hline
\end{tabular}


Statistical analysis

The aim of the statistical analysis was to relate changes in phytoplankton community composition with changes of the environmental descriptors, i.e. physico-chemical parameters and msPAF. Constrained analysis was applied using redundancy analysis (RDA, Fig. 1) following Legendre and Legendre (1998) with the R software (R Development Core Team 2009). Furthermore, partial redundancy (pRDA) was employed to underline the changes in phytoplankton species due to the msPAF gradient only. Indeed, the main goal was to find which species were significantly influenced by this toxicity gradient after accounting for the variation explained by other environmental factors.

RDA allows investigation into how a matrix of explanatory variables could explain a matrix of response variables and is commonly employed in ecology. The data matrix of explanatory variables was composed with all the physicochemical parameters as well as with the msPAF during spring sampling dates from 2004 to 2009. The msPAF was considered to be constant from March to May each year and the value of April was used for the analysis. This hypothesis was supported by the fact that the herbicide concentrations did not significantly vary in the lake during the year (Chèvre et al. 2008). The Mann-Kendall statistical test (Mann 1945; Kendall 1955) was employed to detect trends in the time series of the explanatory variables. Moreover, one variable called "sampling time", expressing the day and month of each sampling date in any given year, was added to the explanatory variables. Indeed, inter-annual natural temporal trends of phytoplankton during these 3 months could be one explanation factor of the species abundance variation in the community composition. The response data matrix of species abundance was composed with the concentration of counted algal objects, measured at SHL2 for each species of phytoplankton, for the same dates as the explanatory variables. Before the RDA, each species variable was scaled by its standard deviation. Indeed, algal objects between the different species were not always similar and needed to be made comparable. Moreover, only strong and occasionally dominant species were retained, i.e. species with an annual average relative abundance of less than $1 \%$ for all years were eliminated (Padisák et al. 2010; Anneville et al. 2002). Rare species were regarded as not suitable for the calculation as the accuracy of their measurement was not fully reliable. In the end, the response matrix was composed of a community of 38 different species (Table 2) with species abundance for 33 sampling dates. The redundancy analysis was performed with a Hellinger-transformed response matrix to make this data table more suitable for analysis as the community composition contained many abundance values equal to zero (Legendre and Gallagher 2001). After the constraint analysis, the Variance Inflation Factors
(VIF's) were used to identify multicollinearity between explanatory variables. A common rule is that VIF values over 10 indicate redundant constraints (Kutner et al. 2004; Chatterjee and Hadi 2006) and variables concerned were excluded from the canonical analysis.

Finally, significance tests of constraints for RDA and pRDA were carried out using permutation tests (Legendre and Legendre 1998) with a fixed number of 1000 permutations.

\section{Results and discussion}

\section{Mixture risk prediction}

The concentrations of the 14 herbicides are between 0.001 and $0.025 \mu \mathrm{g} \mathrm{L}^{-1}$ for the period from 2004 to 2009 (Table 3). They had a general tendency to slightly decrease during the period studied for all pesticides, except for atrazine, whose concentrations increased in 2008 and 2009. This may be explained by the fact that atrazine was banned in Switzerland in 2010 and stocks were certainly used from 2008 to 2010.

Each herbicide taken individually represented a negligible risk, i.e. with a ratio clearly below one, when comparing the concentrations to the HC5 (Table 3). The highest risk values were for the herbicides diuron and monolinuron and reached a maximum RQ of 0.2 in 2005 and 2004 respectively. The concentration of these two substances corresponded individually to a predicted fraction of affected species of $1 \%$ during these years, according to their NOEC-SSD.

In contrast, the percentage of species potentially affected by the mixture was somewhat higher, reaching a maximum of $3.2 \%$ in 2005 (Fig. 2a). It afterwards significantly decreased until reaching $0.66 \%$ in 2009 (Kendall's Tau $=-0.804,2$-sided $p$ value $<0.0001)$. This can be explained by the constant decrease of most of the herbicides concentrations during the period. The increase of atrazine did not have much influence in the mixture toxicity as it is one of the less toxic triazines, as confirmed in Chèvre et al. (2006). The group of phenylureas contributed around $70 \%$ to mixture toxicity over the whole period. For example, in 2005 , when the toxicity of the whole mixture reached a maximum, with an msPAF of species of $3.2 \%$, phenylureas alone affected already $2.2 \%$ of species. The most important contributors to mixture toxicity were by far within the phenylureas, monolinuron and diuron. The triazines alone yielded a maximum prediction of $0.65 \%$ of affected species in 2005 , where the whole mixture predicts $3.2 \%$. The principal contributors of toxicity for triazines were the terbutryn and the prometryn. In general, the contribution of the metolachlor alone to the toxicity of the whole mixture was comparable to that of the group of triazines (Table 3). 
Table 2 Most abundant species in spring phytoplankton community composition during 2004 to 2009 at the sampling point SHL2 of Lake Geneva
They form the response matrix used for the redundancy analysis. Classes indicated by: CYA cyanophyte; DIN dinoflagellate; $C R Y$ cryptophyte; $C H R$ chrysophyte; $B A C$ bacillariophyceae; $C H L$ chlorophyte; $P R Y$ prymnesiophyceae; TRE trebouxiophycae; $X A N$ xanthophyte; $Z Y G$ zygnematophyceae

\begin{tabular}{|c|c|c|}
\hline Selected species & Abbreviation & Classe \\
\hline Achnanthidium minutissimum (Kützing) Czarnecki & Ach & $\mathrm{BAC}$ \\
\hline Aphanizomenon flos aquae Ralfs ex Bornet and Flahault & Aph1 & CYA \\
\hline Aphanocapsa holsatica (Lemmermann) G. Cronberg and J. Komárek & Aph2 & CYA \\
\hline Asterionella formosa Hassall & Ast & BAC \\
\hline Aulacoseira islandica ssp. Helvetica (O. Muller) & Aul & BAC \\
\hline C. aciculare T.West & Clo & $\mathrm{ZYG}$ \\
\hline Ceratium hirundinella (O. F. Muller) Dujardin & Cer & DIN \\
\hline Chlamydomonas conica P. A. Dangeard & Chl1 & $\mathrm{CHL}$ \\
\hline Chlamydomonas sp. & $\mathrm{Ch} 12$ & $\mathrm{CHL}$ \\
\hline Chlorella vulgaris Beyerinck & Chl3 & TRE \\
\hline Choricystis cf. minor (Skuja) Fott & Cho & $\mathrm{CHL}$ \\
\hline Cryptomonas sp. & Cry & CRY \\
\hline Cyclotella costei Druart and Straub & Cyc1 & BAC \\
\hline Diatoma tenuis Agardh & Dia & BAC \\
\hline Erkenia subaequiciliata Skuja & Erk & PRY \\
\hline Fragilaria crotonensis Kitton & Fra1 & BAC \\
\hline Gymnodinium helveticum Penard & Gym1 & DIN \\
\hline Gymnodinium lantzschii Utermohl & Gym2 & DIN \\
\hline M. gracillima (Hassall) Wittrock & Mou & $\mathrm{ZYG}$ \\
\hline Ochromonas sp. & Och & CHR \\
\hline Oscillatoria cf. janus Skuja & Osc & CYA \\
\hline Peridinium willei Huitfeldt-Kaas & Per & DIN \\
\hline Planktothrix rubescens (De Candolle ex Gomont) Anagnostidis and Komárek & $\mathrm{Pla}$ & CYA \\
\hline Pseudanabaena galeata Böcher & Pse1 & CYA \\
\hline Pseudanabaena limnetica (Lemmermann) Komarek & Pse2 & CYA \\
\hline Puncticulata radiosa (Lemmermann) Håkansson & Cyc2 & BAC \\
\hline Rhodomonas minuta Skuja & Rho1 & CRY \\
\hline Rhodomonas minuta v. nannoplanctica H.Skuja & Rho2 & CRY \\
\hline Staurastrum messikomerii f. planctonicum & Sta1 & $\mathrm{ZYG}$ \\
\hline Staurastrum sebaldii $v$. ornatum Nordstedt & Sta2 & $\mathrm{ZYG}$ \\
\hline Stephanodiscus alpinus Hustedt & Ste1 & BAC \\
\hline Stephanodiscus minutulus (Kutzing) Cleve and Moller & Ste2 & BAC \\
\hline Stephanodiscus neoastrae Hakansson and Hickel & Ste3 & $\mathrm{BAC}$ \\
\hline Synechococcus elongatus (Nägeli) Nägeli & Syn & CYA \\
\hline Tribonema sp. & Tri & XAN \\
\hline Ulnaria delicatissima var.angustissima (Grunow) Compère & Fra3 & BAC \\
\hline Ulnaria ulna var. acus (Kützing) Lange-Bertalot & Fra2 & BAC \\
\hline Undetermined small Chlorophycae & Chl4 & CHL \\
\hline
\end{tabular}

Physico-chemical parameter fluctuations

The inter-annual variations show that total phosphorus concentrations decreased significantly from an average of $0.024 \mathrm{mg} \mathrm{L}^{-1}$ in 2004 to an average of $0.02 \mathrm{mg} \mathrm{L}^{-1}$ in 2009 (Fig. 2b; Kendall's Tau $=-0.327,2$-sided $p$ value $=0.008$ ). This general tendency to decline has been observed for many years due mostly to the ban of phosphates in washing powders and improvements in the treatment of the wastewaters in the catchment. DIN shows also a similarly significant trend and decreased from an average of $0.58 \mathrm{mg} \mathrm{L}^{-1}$ in 2004 to an average of $0.34 \mathrm{mg} \mathrm{L}^{-1}$ in 2009 (Fig. 2c; Kendall's Tau $=0.446$, 2-sided $p$ value $=0.0003)$. In contrast, temperature increased over the years, but less significantly (Fig. 2d; Kendall's Tau $=0.216$, 2-sided pvalue $=0.08$ ). An explanation could be global warming since such a temperature rise has also been observed in Swiss rivers (Hari et al. 2006). All other physico-chemical parameters did not show a significant trend during this period as can be seen visually from Fig. $2 \mathrm{e}-\mathrm{h}$.

The intra-annual variations are characterized by a decrease in dissolved inorganic phosphorous and nitrates over March, April and May (Fig. 2b-c). These drops 
Table 3 Maximal and minimal herbicides concentration and risk in Lake Geneva found at sampling point SHL2 for the springtime between 2004 and 2009

\begin{tabular}{|c|c|c|c|}
\hline Substances & Concentration $\max -\min \left(\right.$ year $_{\max }-$ year $\left._{\min }\right)$ & $\mathrm{HC}_{5}$ & Individual risk $_{\max }-$ risk $_{\min }$ \\
\hline Atrazine & $0.027-0.009$ (2004-2007) & 1.86 & 0.01 to 0.005 \\
\hline Prometryn & $0.007-0.001(2004-2009)$ & 0.17 & 0.04 to 0.006 \\
\hline Simazine & $0.013-0.002(2004-2009)$ & 3.31 & 0.004 to 0.001 \\
\hline Terbumeton & $0.004-$ nd (2004-2009) & 0.31 & 0.011 to $\approx 0$ \\
\hline Terbuthylazine & $0.013-0.002(2004-2009)$ & 0.37 & 0.035 to 0.004 \\
\hline Terbutryn & $0.003-$ nd (2005-2004) & 0.03 & 0.111 to $\approx 0$ \\
\hline Diuron & $0.01-0.002(2005-2009)$ & 0.05 & 0.184 to 0.039 \\
\hline Chlorotoluron & $0.009-0.001$ (2004-2009) & 0.37 & 0.024 to 0.003 \\
\hline Isoproturon & $0.008-0.001(2006-2008 / 09)$ & 0.24 & 0.032 to 0.004 \\
\hline Linuron & 0.003-nd (2004-2008) & 0.25 & 0.01 to $\approx 0$ \\
\hline Metobromuron & $0.01-$ nd $(2004 / 2009)$ & 4.03 & 0.002 to $\approx 0$ \\
\hline Monolinuron & 0.014-nd (2004-2007/08) & 0.06 & 0.22 to $\approx 0$ \\
\hline Monuron & 0.003-nd (2004-2007/08/09) & 5.08 & 0.001 to $\approx 0$ \\
\hline Metolachlor & $0.016-0.003$ (2004-2008) & 0.23 & 0.06 to 0.013 \\
\hline By TMoA & \multicolumn{2}{|c|}{ Concentration max-min $\left(\right.$ year $_{\max }-$ year $\left._{\min }\right)$} & Potentially Affected Fraction \\
\hline Equi Atrazine (Triazine) & \multicolumn{2}{|l|}{$0.377-0.108(2005-2009)$} & $0.65-0.13\left(\mathrm{msPAF}_{\mathrm{CA}} \max -\min \right)$ \\
\hline Equi Diuron (Phenylurea) & \multicolumn{2}{|l|}{$0.023-0.003$ (2004-2009) } & $2.28-0.25\left(\mathrm{msPAF}_{\mathrm{CA}} \mathrm{max}-\mathrm{min}\right)$ \\
\hline Metolachlor & \multicolumn{2}{|l|}{$0.016-0.003$ (2004-2009) } & $0.42-0.09$ (PAF max-min) \\
\hline
\end{tabular}

The second column gives the max-min concentration and, in brackets, the year they occur. The third column gives the hazardous concentration for $5 \%$ of the algae species (HC5). The individual max-min risk in the fourth column corresponds to the ratio between max-min concentration and $\mathrm{HC}_{5}$. The second part of the table presents the max-min equivalent concentration (second column) by TMoA expressed in a reference substance (concentrations of metolachlor are directly reported as it is the only one compound in the TMoA of cell division inhibitors). The last column gives the max-min potentially affected fraction of species of algae expressed as a percentage $\left(\mathrm{msPF}_{\mathrm{CA}}\right.$ for mixture, PAF for metolachlor) based on the max-min concentration in each TMoA. Concentrations are express in $\mu \mathrm{g} \mathrm{L}^{-1}$, nd not detected

coincided with an increase in the photosynthetic activity of phytoplankton during the spring period. The DIN:DIP ratios indicated a phosphorus limitation with values (average of 145 in molar concentrations) well above the Redfield ratio, which is $16: 1$ for optimal phytoplankton growth (Redfield 1958). Temperature shows a constant increase from March to May due to seasonal variation (Fig. 2d).

Identification of the variables influencing phytoplankton fluctuations

The first step of the method was to identify redundancy in the variables. Measures of linear dependence between environmental variables showed a strong correlation between variables "sampling time" and temperature $(r>0.8)$. This seems logical as the temperature characterized well the sampling period in spring, with constant increases from March to May for each year. Another strong correlation was found between total phosphorus and the ratio TN:TP $(r<-0.8)$. These two variables "sampling time" and the ratio TN:TP had a high VIF value after the constraint analysis and were therefore eliminated. Afterwards, VIF values were $<7$ for all the remaining variables, suggesting the absence of strong collinearity problems.

The best explanatory and the most significant variables to explain variations of species abundance in the phytoplankton community composition from 2004 to 2009 at SHL2, if only one environmental variable was used in $\mathrm{RDA}$, are listed here in decreasing order of importance: msPAF, total phosphorus, temperature, dissolved inorganic phosphorus and dissolved inorganic nitrogen (Table 4). Selected environmental variables in the redundancy analysis collectively explain a total of $38 \%$ of the variation in phytoplankton community composition, with a high significance (Table 5). The first constrained axis is significant and accounts for $11 \%$ of the variance. This one is principally negatively correlated to msPAF, total phosphorus and dissolved inorganic phosphorus and positively correlated with temperature (Table 5). The first axis therefore represents mainly a gradient over time, which separate the samples from the highest msPAF and total phosphorus values on the left to the lowest values (Fig. 3). As mentioned before, the first two variables decreased significantly over the years and it seems logical that phosphorus appears as an important driver due to its scarcity. The temperature 
A
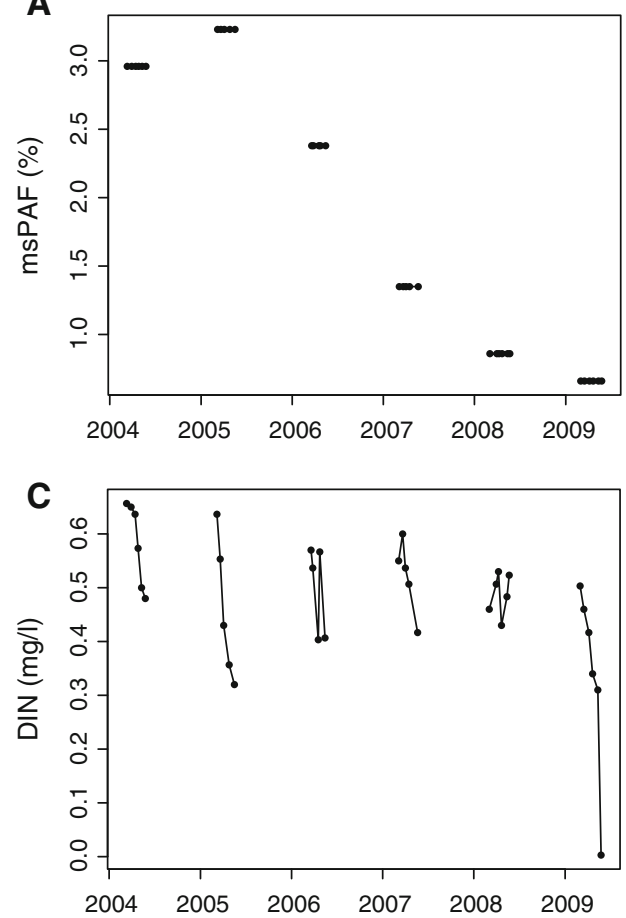

E

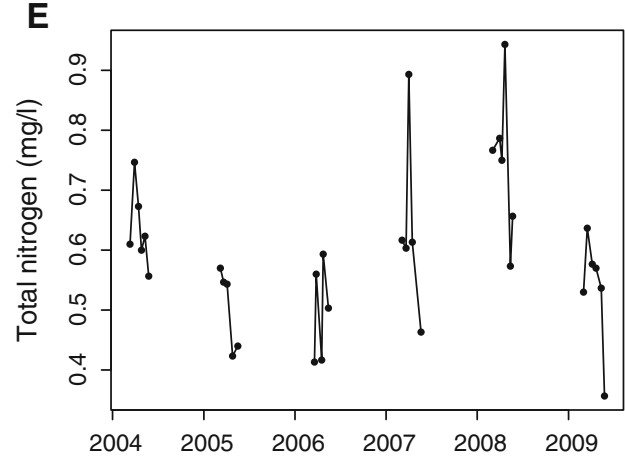

G

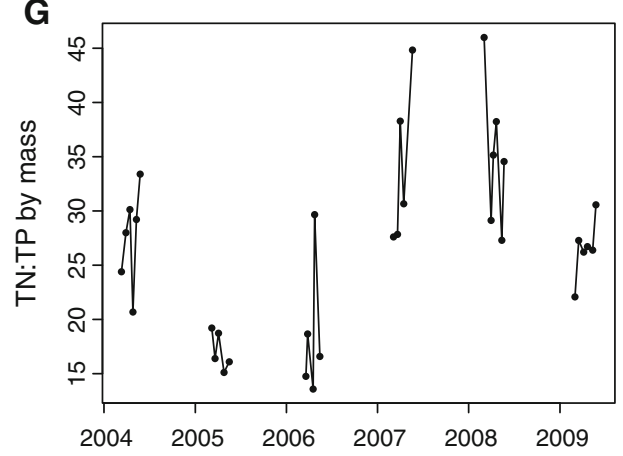

B
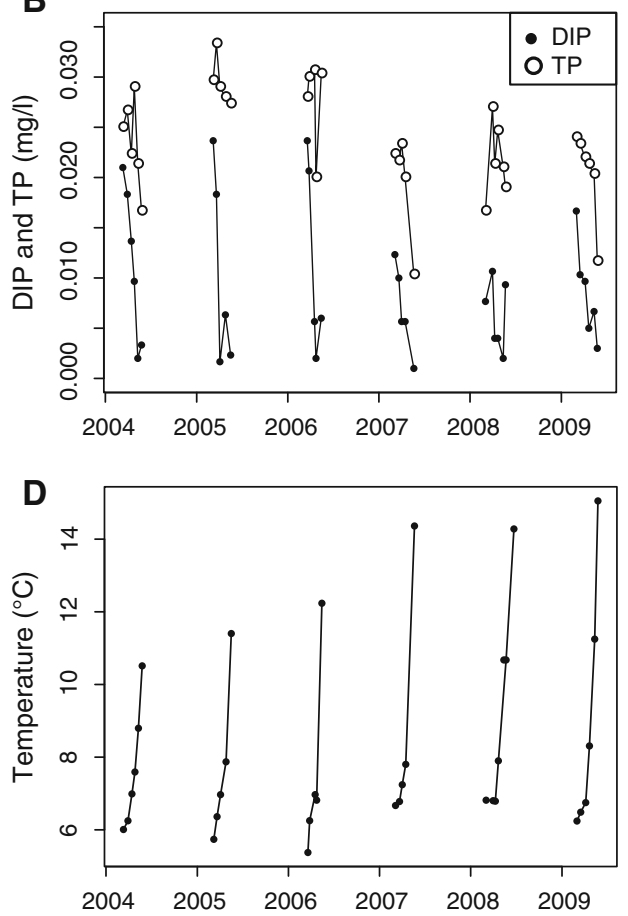

$\mathbf{F}$

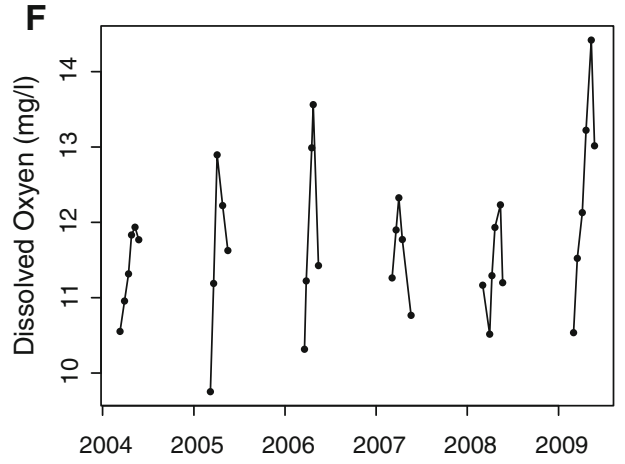

H

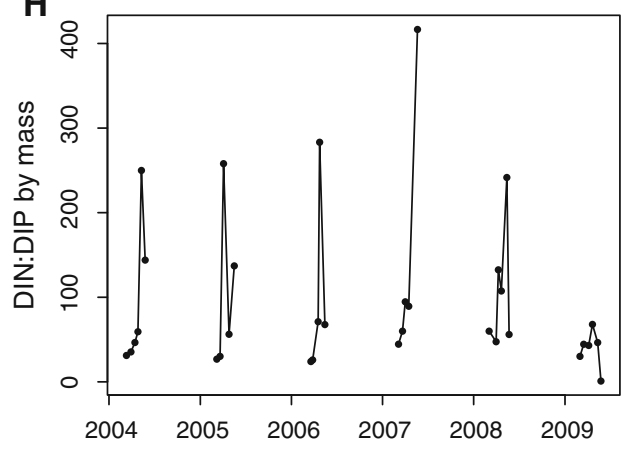

phosphorus (DIP) and total phosphorus (TP) (b), in dissolved inorganic nitrogen (DIN) (c), in temperature (d), in total nitrogen (TN) (e), in dissolved oxygen (f), in the ratio of TN to TP (g) and the ratio of DIN to DIP (h)

because of its stronger intra-annual variation, but it showed a significant increase over the years as well. The second axis explains $7 \%$ of the variance, but msPAF is not perature on the left and a higher on the right (Fig. 3). However, the temperature was less correlated with this axis
(March-May) in Lake Geneva at the sampling point SHL2 (middle of the Lake) from 2004 to 2009. Variation in multi-substance potentially affected fraction of species (msPAF) concerning the toxicity on phytoplankton community (a), in dissolved inorganic

gradient goes in an opposite direction with a lower tem- 
Table 4 Marginal effects for the data of Geneva Lake at sampling point SHL2 from 2004 to 2009

\begin{tabular}{lll}
\hline Variable & $\begin{array}{l}\text { Variation explained by } \\
\text { each variable used } \\
\text { individually }\end{array}$ & $P$ \\
\hline MsPAF & 9.07 & 0.001 \\
Total phosphorus & 7.73 & 0.001 \\
Temperature & 6.38 & 0.004 \\
DIP & 5.03 & 0.032 \\
DIN & 4.32 & 0.084 \\
Dissolved oxygen & 4.07 & 0.129 \\
Total nitrogen & 3.75 & 0.221 \\
DIN:DIP & 2.86 & 0.581 \\
\hline
\end{tabular}

The second column shows the percentage of variance of spring phytoplankton community explained with the RDA by using only one variable of the explanatory matrix. The third column shows the $p$-values obtained by the permutation test for the RDA

Table 5 Percentage of variance of spring phytoplankton community explained by all explanatory variables, with RDA of data of Lake Geneva at sampling point SHL2 from 2004 to 2009

\begin{tabular}{lccc}
\hline RDA constrained axis & Axis $1 * * *$ & Axis $2^{*}$ & All axes \\
\hline Cumulative variation explained & 11.1 & 18.2 & $38^{* * *}$ \\
\hline Environmental variables & & & \\
msPAF & $-0.84^{* * *}$ & -0.11 & \\
Total phosphorus & $-0.70^{* * *}$ & $0.51^{* *}$ & \\
Temperature & $0.54^{* * *}$ & 0.01 & \\
DIP & $-0.42^{*}$ & $-0.36^{*}$ & \\
DIN & -0.29 & -0.29 & \\
Total nitrogen & 0.29 & 0.10 & \\
Dissolved oxygen & 0.17 & $0.38^{*}$ & \\
DIN:DIP & 0.16 & -0.04 &
\end{tabular}

Asterisks correspond to results from the permutation test for axis significance. The second part of the table corresponds to the Pearson correlations $(r)$ between environmental variables and the two first axes. $(* * * p \leq 0.001<* * p<0.01<* p<0.1)$

significantly correlated with this axis (Table 5). Other constrained axes were no more significant.

Thus, RDA results showed that total phosphorus and msPAF values explained most strongly the variance on the first axis, making it difficult to distinguish between species that were more related to one or another. Therefore, we applied a partial RDA by means of a separation of msPAF from all other parameters. This separation made it possible to explore the relations between msPAF and the residual species abundance of community composition after having removed the effect of phosphorus and all other environmental covariables. Moreover, it also removed the intra-annual variation that could be ascribed to natural variability over time.

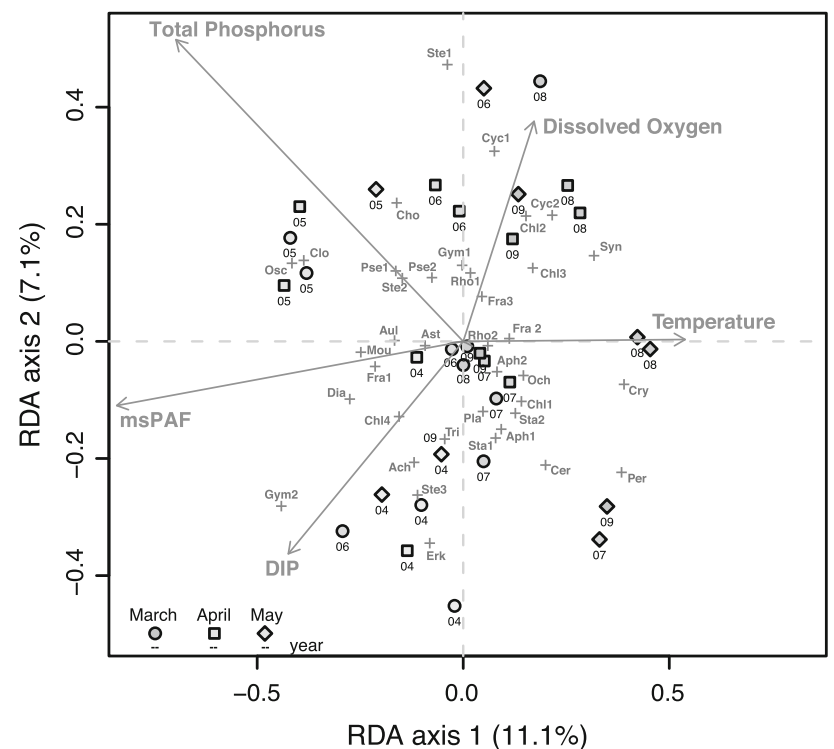

Fig. 3 RDA between physico-chemical data (explanatory variables matrix) and spring phytoplankton community composition (response variables matrix) at the sampling point SHL2 of Lake Geneva from 2004 to 2009. The figure shows the RDA triplot on the two first significant constrained axes with algae species (crosses), sampling dates (symbols), and the significant environmental variables (arrows). Axis one explains $11.1 \%$ of the species variance and axis two $7.1 \%$. The length of an arrow projected onto an axis is relative to the importance of the variable in assemblage ordination on this axis. Species abbreviations correspondence is given in Table 2

Indeed, the temperature considered in covariables was strongly correlated with the "sampling time" in each year.

Results of the variation partitioning with pRDA showed that the variation in spring phytoplankton community, explained by msPAF after accounting for other covariables, corresponds to $6 \%$ and is still significant with a permutation test $(P=0.001)$. Indeed, all other covariables explained $32 \%$ of the variation, with $3 \%$ being shared with msPAF. In this manner, the pRDA of msPAF resulted in only one constrained axis and msPAF correlated significantly with it $(r=-0.65, P<0.001)$. Figure 4 shows species whose residual relative abundance, i.e. after removing all other factors from the response table, is most significantly correlated with this constrained axis by msPAF. Therefore, it gives an indication of their covariance with the mixture toxicity of herbicides and it can be argued that they could have been influenced positively or negatively in relative abundance by the change in this variable.

A close look at the species linked positively or negatively to the msPAF gradient (Fig. 4), revealed by the partial RDA, shows interesting correspondences with others studies on the effects of herbicides on species composition with meso/ microcosm experiments. Indeed, the trend resulting from the partial RDA whereby algae Fragilaria crotonensis and Asterionella formosa were favourably influenced by the increase of herbicide contamination was also observed in 
Pearson's product moment correlation coefficient

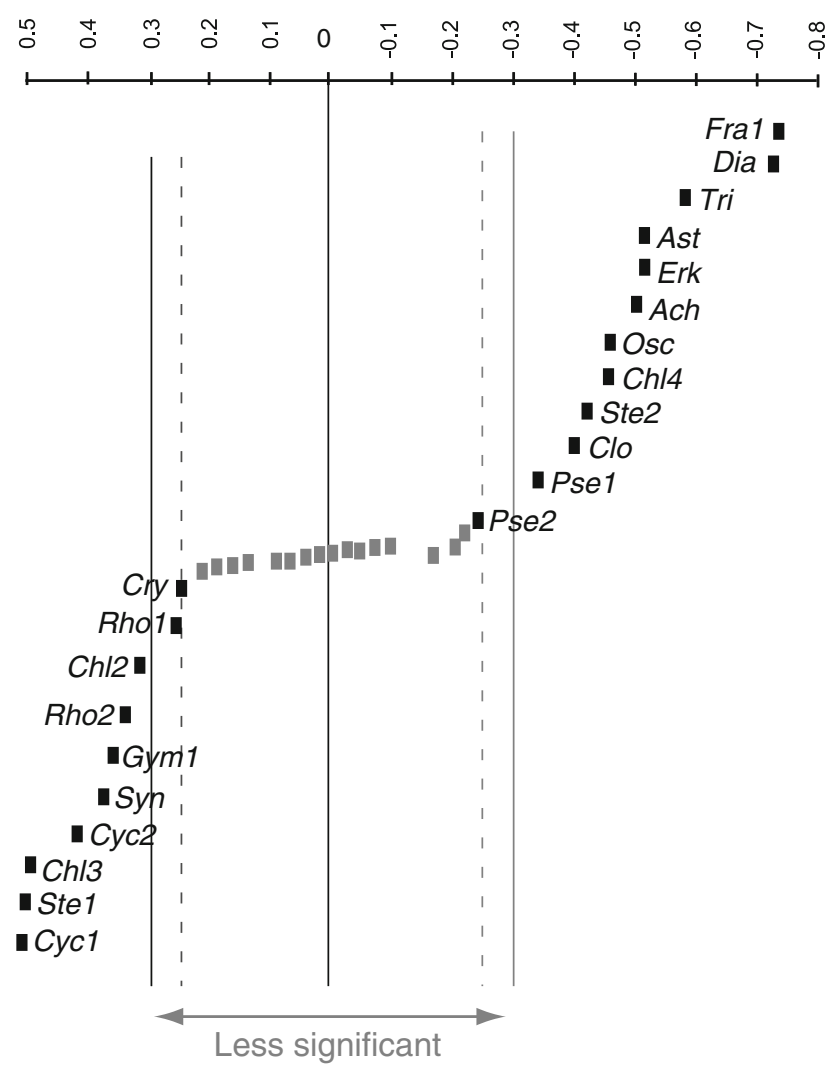

Fig. 4 Trend of phytoplankton species' fluctuations in the community composition linked with herbicide mixture toxicity changes, at sampling point SHL2 from 2004 to 2009. It shows the significant correlation of the residual variation in species abundance in the community composition, i.e. after removing the effect of other physico-chemical variables, with the first constrained axis of the pRDA. 22 species were found to be significantly correlated, and this axis is also significantly negatively correlated with msPAF. Therefore, the species on the right are more abundant in community composition with higher mixture toxicity while species on the left becomes more abundant with lower mixture toxicity. The species correlation beyond the solid line obtains a $p$ value $<0.05$ and beyond the dashed line a $p$ value $<0.1$. Species abbreviations are given in Table 2

outdoor micro/nanocosm contaminated by atrazine with algae strains from Lake Geneva (Bérard et al. 1999a, b; Bérard and Benninghoff 2001). The same correspondence can be made for Achnanthidium minutissimum, which was favored in communities exposed to triazines (Debenest et al. 2010). This species also shows a positive correlation with the herbicide mixture toxicity at SHL2 (Fig. 4). Some species, however, show an increase in abundance in the community composition when the herbicide mixture becomes less toxic (Fig. 4). A decrease of species abundance in the community for Chlorella vulgaris and Chlamydomonas sp. (Bérard et al. 2003; Bérard and Benninghoff 2001; Nyström et al. 2002) and more generally of the Cryptophyecae (CRY) class (Knauer et al. 2010) had already been reported in meso/microcosm studies. This trend for these species is in agreement with the partial RDA results at SHL2 (Fig. 4).

Discussion of the method

The results showed that the herbicide mixture toxicity has a significant influence to in explaining a part of the variance in species abundance in the phytoplankton community. However, not all the herbicides have the same potency in the mixture and it's clear that the toxicity of the mixture is driven by key herbicides. Both diuron and monolinuron accounted for about $65 \%$ of the total msPAf. This percentage reached $80 \%$ by taking into account terbutryn, prometryn and tebutylazine. For mixture risk assessment, it is therefore crucial to consider these substances for calculation. Furthermore, this point also has some implications for risk management since the most important decrease of risk can be obtained by reducing the pollution caused by these specific chemicals.

In the case of Lake Geneva, herbicide mixture toxicity was low (with a maximum msPAF of $3 \%$ ). Even if it appeared as a significant parameter to explain phytoplankton fluctuations, one could therefore ask if it is really meaningful and if we were not working at the limits of the method. To be able to answer this criticism, it would have been better to have distinctively contrasted zones in terms of herbicide concentrations in order to better differentiate the gradient of mixture toxicity from other co-variables, especially the natural variability of the species relative abundance in time or due to phosphorus concentration fluctuations. Furthermore, even if the risk model predicts that a small fraction of species will be affected, it cannot be ruled out that herbicides could have a significant impact on some particular sensitive organisms. It would be interesting to compare the lake species, which were linked positively or negatively with msPAF gradient (Fig. 4), and their sensitivity to herbicides based on their place on the SSD. For example, Synechococcus species are among the most sensitive in the SSD of diuron, linuron and atrazine. This algae genus actually seems more sensitive than most of other algae, and Synechococcus elongatus is negatively correlated with the toxicity gradient in our result for Lake Geneva at SHL2 from 2004 to 2009. Unfortunately, this is not feasible for other lake species due to the lack of ecotoxicity data.

Moreover, effects of herbicides on photosynthesis organisms with very low concentrations have been observed in some mesocosm studies. For example, chronic effects on freshwater periphyton communities were observed at diuron concentrations lower than $0.1 \mu \mathrm{g} \mathrm{L} \mathrm{L}^{-1}$ (McClellan et al. 2008; Ricart et al. 2009). In our case study, the sum of equivalent concentrations expressed as diuron for all substances in the phenylureas TMoA, i.e. corresponding to a total diuron concentration, was up to 
$0.023 \mu \mathrm{g} \mathrm{L}^{-1}$. Similarly, Pannard et al. (2008) showed the toxicity of low doses of atrazine $\left(0.1 \mu \mathrm{g} \mathrm{L}^{-1}\right)$ on the phytoplankton community when associated with changes in nutrient availability. Indeed, resource competition enhanced community sensitivity, and the presence of atrazine in this case should be considered as chronic stress, which inhibited the most sensitive organisms and changed the phytoplankton community structure. This may be magnified in natural open systems. In our study, the sum of equivalent concentrations expressed as atrazine, for all triazines, was always higher than $0.1 \mu \mathrm{g} \mathrm{L}^{-} 1$. When we add the equivalent concentrations of diuron and metolachlor, it becomes likely that herbicides in combination act as a chronic stress and influence phytoplankton at SHL2.

In conclusion, our results show that herbicide mixture toxicity can play a role in phytoplankton community changes in a natural system. Indeed, the gradient of the prediction of mixture toxicity used in risk assessment from 2004 to 2009 explain a significant part of the variance in phytoplankton community composition for some species even after accounting for other confounding environmental factors. It doesn't prove a direct effect of herbicides but provides some evidence of the impact of these chemicals on the aquatic system on terms of which species would benefit in relative abundance from the change in toxicity. Therefore, this kind of study, which integrates ecotoxicology and ecology, also allows ecotoxicological testing to be adjusted by focusing on highlighted species (for example, very sensitive species). For further research, it would be interesting to compare not only the abundance, but also the changes of functional traits in the phytoplankton communities (Van den Brink et al. 2011) in order to better understand the effects of the herbicides on the role that these influenced species play in the ecosystem.

Acknowledgments This project is part of the FNS Prodoc Project Leman21. The authors want to acknowledge the Swiss National Science Foundation (Grant number PDFMP2-123048/1) and the Ministère français de l'Ecologie, de l'Energie, du Développement Durable et de l'Aménagement du Territoire (convention 2100212555) for funding this study. The data used in this study were kindely provided by the CIPEL (The International Commission on Geneva lake Survey) and by INRA-Thonon (phytoplankton SOERE database).

Conflict of interest The authors declare that they have no conflict of interest.

\section{References}

AGRITOX (2012) Database for pesticides. http://www.dive.afssa. fr/agritox/index.php. Accessed August 2011

Altenburger R, Backhaus T, Boedeker W, Faust M, Scholze M, Horst Grimme L (2000) Predictability of the toxicity of multiple chemical mixtures to Vibrio fischeri: mixtures composed of similarly acting chemicals. Environ Toxicol Chem 19(9):23412347. doi:10.1002/etc.5620190926
Anneville O, Ginot V, Druart JC, Angeli N (2002) Long-term study (1974-1998) of seasonal changes in the phytoplankton in Lake Geneva: a multi-table approach. J Plankton Res 24(10): 993-1008. doi:10.1093/plankt/24.10.993

Barnthouse L (2008) The strengths of the ecological risk assessment process: linking science to decision making. Integr Environ Assess Manage 4(3):299-305. doi:10.1897/IEAM_ 2007-065.1

Beketov MA, Liess M (2011) Ecotoxicology and macroecology: time for integration. Environ Pollut 162:247-254. doi:10.1016/ j.envpol.2011.11.011

Bérard A, Benninghoff C (2001) Pollution-induced community tolerance (PICT) and seasonal variations in the sensitivity of phytoplankton to atrazine in nanocosms. Chemosphere 45(4-5): 427-437. doi:10.1016/S0045-6535(01)00063-7

Bérard A, Leboulanger C, Pelte T (1999a) Tolerance of Oscillatoria limnetica Lemmermann to Atrazine in natural phytoplankton populations and in pure culture: influence of season and temperature. Arch Environ Contam Toxicol 37(4):472-479. doi: 10.1007/s002449900541

Bérard A, Pelte T, Druart JC (1999b) Seasonal variations in the sensitivity of Lake Geneva phytoplankton community structure to atrazine. Archiv für Hydrobiologie 145(3):277-295

Bérard A, Dorigo U, Mercier I, Becker-Van Slooten K, Grandjean D, Leboulanger C (2003) Comparison of the ecotoxicological impact of the triazines Irgarol 1051 and atrazine on microalgal cultures and natural microalgal communities in Lake Geneva. Chemosphere 53(8):935-944. doi:10.1016/S0045-6535(03)00674-X

Chatterjee S, Hadi AS (2006) Regression analysis by example, 4th edn. Wiley., Hoboken

Chèvre N, Gregorio V (2012) Interactions in ecotoxicology. In: Blaise C, Ferrard JF (eds) Comprehensive handbook of ecotoxicological terms, Elsevier, New York (In press)

Chèvre N, Loepfe C, Singer H, Stamm C, Fenner K, Escher B (2006) Including mixtures in the determination of water quality criteria for herbicides in surface water. Environ Sci Technol 40(2): 426-435. doi:10.1021/es0502391

Chèvre N, Loepfe C, Fenner K, Singer H, Escher B, Stamm C (2007) Pesticides in Swiss surface water : effect-based quality criteria. Gas Wasser Abwasser 7:529-539

Chèvre N, Edder P, Ortelli D, Tatti E, Erkman S, Rapin F (2008) Risk assessment of herbicide mixtures in a large European lake. Environ Toxicol 23(2):269-277. doi:10.1002/tox.20337

Corvi C, Zimmerli P, Ortelli D, Khim-Heang S, Becker-Van Slooten $\mathrm{K}$ (2005) Metals and micropollutants in the water, mussels and fish of lake Geneva. Report from CIPEL Campaign 2004, Changins, pp 55-78

de Zwart D, Posthuma L (2005) Complex mixture toxicity for single and multiple species: proposed methodologies. Environ Toxicol Chem 24(10):2665. doi:10.1897/04-639R.1

Debenest T, Silvestre J, Coste M, Pinelli E (2010) Effects of pesticides on freshwater diatoms. Rev Environ Contam Toxicol 203:87-103. doi:10.1007/978-1-4419-1352-4_2

Druart JC (2007) The phytoplankton of lake Geneva. Report from CIPEL Campaign 2006, Changins, pp 83-92

Druart JC, Rimet F (2008) Protocoles d'analyse du phytoplancton de l'INRA : prélèvement, dénombrement et biovolumes. Report from INRA, Thonon les Bains

Druart JC, Rolland A, Tadonleke R (2005) Changes in the phytoplankton of lake Geneva. Report from CIPEL Campaign 2004, Changins, pp 79-89

Druart JC, Robert M, Tadonleke R (2006) The phytoplankton of lake Geneva. Report from CIPEL Campaign 2005, Changins, pp 89-100

eChemPortal (2011) The global portal to information on chemical substances. http://www.echemportal.org. Accessed August 2011 
ECOTOX (2012) The ecotoxicology database, U.S. Environmental Protection Agency. http://cfpub.epa.gov/ecotox. Accessed August 2011

Edder P, Ortelli D, Ramseier S (2006) Metals and organic micropollutants. Report from CIPEL Campaign 2005, Changins, pp 65-87

Edder P, Ortelli D, Ramseier S, Chèvre N (2007) Metals and organic micropollutants in Geneva lake waters. Report from CIPEL Campaign 2006, Changins, pp 59-81

Edder P, Ortelli D, Klein A, Ramseier S (2008) Metals and organic micropollutants in Geneva lake waters and sediments. Report form CIPEL Campaign 2007, Changins, pp 57-84

EFSA (2012) European Food Safety Authority. http://www.efsa. europa.eu/en/publications.htm. Accessed August 2011

EN 15204 (2006) Water quality: guidance standard on the enumeration of phytoplankton using inverted microscopy (Utermöhl Technique). European Committee for Standardization, Brussels

European Commission (2003) Technical guidance document on risk assessment TGD. Part II. Institute for health and consumer protection, European Chemicals Bureau, European Commission (EC), Ispra

Faust M, Altenburger R, Backhaus T, Blanck H, Boedeker W, Gramatica P, Hamer V, Scholze M, Vighi M, Horst Grimme L (2003) Joint algal toxicity of 16 dissimilarly acting chemicals is predictable by the concept of independent action. Aquat Toxicol 63(1):43-63. doi:10.1016/S0166-445X(02)00133-9

FOOTPRINT (2010) Functional tools for pesticide risk assessment and management. http://www.eu-footprint.org/ppdb.html. Accessed August 2011

Hari RE, Livingstone DM, Siber R, Burkhardt-Holm P, Guttinger H (2006) Consequences of climatic change for water temperature and brown trout populations in Alpine rivers and streams. Glob Change Biol 12:10-26. doi:10.1111/j.1365-2486.2005.001051.x

INERIS (2012) Institut national de l'environnement industriel et des risques. http://www.ineris.fr. Accessed August 2011

Junghans M, Backhaus T, Faust M, Scholze M, Horst Grimme L (2003) Predictability of combined effects of eight chloroacetanilide herbicides on algal reproduction. Pest Manag Sci 59(10): 1101-1110. doi:10.1002/ps.735

Kendall M (1955) Rank correlation methods, 2nd edn. Charles Griffin, London

Knauer K, Leimgruber A, Hommen U, Knauert S (2010) Co-tolerance of phytoplankton communities to photosynthesis II inhibitors. Aquat Toxicol 96(4):256-263. doi:10.1016/j.aquatox.2009. 11.001

Kortenkamp A (2011) Setting the scene: is mixtures risk assessment necessary and feasible? 3rd SETAC Europe special science symposium, prospective and retrospective environmental risk assessment of mixtures: moving from research to regulation, Brussels

Kutner M, Nachtsheim C, Neter J (2004) Applied linear regression models, 4th edn. McGraw-Hill, New York

Lazzarotto J, Rapin F (2007) Physical-chemical changes in the waters of lake Geneva. Report from CIPEL Campaign 2006, Changins, pp 33-57

Lazzarotto J, Rapin F (2008) Physical-chemical changes in the waters of lake Geneva. Report from CIPEL Campaign 2007, Changins, pp 31-55

Lazzarotto J, Rapin F (2009) Physical-chemical changes in the waters of lake Geneva. Report from CIPEL Campage 2008, Changins, pp 33-58

Lazzarotto J, Rapin F (2010) Physical-chemical changes in the waters of lake Geneva. Report from CIPEL Campaign 2009, Chanings, pp 31-56

Lazzarotto J, Rapin F, Corvi C (2005) Physical-chemical changes in the waters of lake Geneva. Report from CIPEL Campaign 2004:31-53
Lazzarotto J, Nirel P, Rapin F (2006) Physical-chemical changes in the waters of lake Geneva. Report from CIPEL Campaign 2005, Changins, Switzerland, pp 31-63 (in french)

Legendre P, Gallagher E (2001) Ecologically meaningful transformations for ordination of species data. Oecologia 129:271-280. doi: $10.1007 / \mathrm{s} 004420100716$

Legendre P, Legendre L (1998) Numerical ecology, 2nd edn. Elsevier Science B.V, Amsterdam

Loos R, Gawlik BM, Locoro G, Rimaviciute E, Contini S, Bidoglio G (2009) EU-wide survey of polar organic persistent pollutants in European river waters. Environ Pollut 157(2):561-568. doi: 10.1016/j.envpol.2008.09.020

Mann HB (1945) Nonparametric tests against trend. Econometrica 13(3):245-259

McClellan K, Altenburger R, Schmitt-Jansen M (2008) Pollutioninduced community tolerance as a measure of species interaction in toxicity assessment. J Appl Ecol 45(5):1514-1522. doi: 10.1111/j.1365-2664.2008.01525.x

Nyström B, Becker-Van Slooten K, Bérard A, Grandjean D, Druart JC, Leboulanger C (2002) Toxic effects of Irgarol 1051 on phytoplankton and macrophytes in Lake Geneva. Water Res 36(8):2020-2028. doi:10.1016/S0043-1354(01)00404-3

OPP (2012) Pesticide ecotoxicity database. Integrated pest management. http://www.ipmcenters.org/Ecotox/dataaccess.cfm. Accessed August 2011

Ortelli D, Edder P, Rapin F, Ramseier S (2009) Metals and organic micropollutants in Geneva lake waters. Report from CIPEL Campaign 2008, Changins, pp 59-71

Ortelli D, Edder P, Rapin F, Ramseier S (2010) Metals and organic micropollutants in rivers and Geneva lake waters. Report from CIPEL Campaign 2009, Changins, pp 57-76

Padisák J, Hajnal E, Krienitz L, Lakner J, Üveges V (2010) Rarity, ecological memory, rate of floral change in phytoplankton-and the mystery of the Red Cock. Hydrobiologia 653(1):45-64. doi: 10.1007/s10750-010-0344-2

Pannard A, Rouzic B, Binet F (2008) Response of phytoplankton community to low-dose atrazine exposure combined with phosphorus fluctuations. Arch Environ Contam Toxicol 57:50-59. doi:10.1007/s00244-008-9245-z

Pesce S, Bouchez A, Montuelle B (2011) Effects of organic herbicides on phototrophic microbial communities in freshwater ecosystems. Rev Environl Contam Toxicol 214:87-124. doi: 10.1007/978-1-4614-0668-6_5

Posthuma L, De Zwart D (2006) Predicted effects of toxicant mixtures are confirmed by changes in fish species assemblages in Ohio, USA, rivers. Environ Toxicol Chem 25(4):1094-1105. doi:10.1897/05-305R.1

Posthuma L, Suter GWI, Traas TP (2002) Species sensitivity distributions in ecotoxicology. Lewis Publishers, Boca Raton

Redfield AC (1958) The biological control of chemical factors in the environment. Am Sci 46(3):205-221

Ricart M, Barceló D, Geiszinger A, Guasch H, López de Alda M, Romaní AM, Vidal G, Villagrasa M, Sabater S (2009) Effects of low concentrations of the phenylurea herbicide diuron on biofilm algae and bacteria. Chemosphere 76(10):1392-1401. doi: 10.1016/j.chemosphere.2009.06.017

Rimet F (2010) The phytoplankton of lake Geneva. Report from CIPEL Campaign 2009, Changins, pp 77-88

Rimet F, Druart JC (2009) The phytoplankton of lake Geneva. Report from CIPEL Campaign 2008, Changins, pp 91-102

Rimet F, Druart JC, Moreau L (2008) The phytoplankton of lake Geneva. Report from CIPEL Campaign 2007, Changins, pp 85-95

Rimet F, Druart JC, Anneville O (2009) Exploring the dynamics of plankton diatom communities in Lake Geneva using emergent self-organizing maps (1974-2007). Ecol Inf 4:99-110. doi: 10.1016/j.ecoinf.2009.01.006 
Schwarzenbach RP, Escher BI, Fenner K, Hofstetter TB, Johnson CA, von Gunten U, Wehrli B (2006) The challenge of micropollutants in aquatic systems. Science 313:1072-1077. doi:10.1126/ science. 1127291

Tadonléké RD, Lazzarotto J, Anneville O, Druart JC (2009) Phytoplankton productivity increased in Lake Geneva despite phosphorus loading reduction. J Plankton Res 31(10): 1179-1194. doi:10.1093/plankt/fbp063

R Development Core Team (2009) R: A language and environment for statistical computing. R Foundation for Statistical Computing, Vienna, Austria. http://www.R-project.org

Van den Brink PJ, Rubach MN, Culp JM, Pascoe T, Maund SJ, Baird DJ (2011) Traits-based ecological risk assessment (TERA): realizing the potential of ecoinformatics approaches in ecotoxicology. Integr Environ Assess Manage 7(2):169-171. doi: 10.1002/ieam.103

Ward S, Augspurger T, Dwyer FJ, Kane C, Ingersoll CG (2007) Risk assessment of water quality in three North Carolina, USA, streams supporting federally endangered freshwater mussels (unionidae). Environ Toxicol Chem 26(10):2075-2085. doi: 10.1897/06-561R.1

Williams RJ, Keller VDJ, Johnson AC, Young AR, Holmes MGR, Wells C, Gross-Sorokin M, Benstead R (2009) A national risk assessment for intersex in fish arising from steroid estrogens. Environ Toxicol Chem 28(1):220-230. doi:10.1897/08-047.1 